\title{
Effects of interleukin-1 $\beta$ on insulin-like growth factor-I autocrine/paracrine axis in cultured rat articular chondrocytes
}

\author{
Tomoko Matsumoto, Tomoo Tsukazaki, Hiroshi Enomoto, Katsuro Iwasaki, \\ Shunichi Yamashita
}

\begin{abstract}
Objective-To clarify the interaction of tissue destruction and repair of articular cartilage during inflammation, the effects

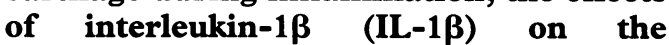
expression of insulin-like growth factor I (IGF-I), its receptor, and its binding proteins were examined.

Methods-Articular chondrocytes from five week rats were cultured in serum free

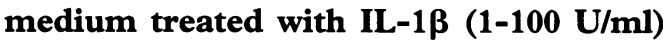
for 24 hours. The concentration of IGF-1 in the conditioned medium was measured by RIA, and IGFBP were analysed by immunoligand blotting method. IGF-I receptors were also examined by [ ${ }^{125}$ I]IGF-I binding study. Results-IL-1 $\beta$ induced the secretion of IGF-I and IGF-binding protein in chondrocytes; this was not inhibited by indomethacin $(5 \mu \mathrm{g} / \mathrm{ml})$. IL-1 $\beta$ also increased the number of IGF-I receptors but had no effect on receptor affinity. IL-1 $\beta$ inhibited chondrocyte proliferation, while exogenous IGF-I and growth hormone stimulated chondrocyte cell growth. IL-1 $\beta$ did not change IGF-I mRNA levels.
\end{abstract}

Conclusion-IL-1 $\beta$ up-regulated the IGF-I autocrine/paracrine axis in cultured articular chondrocytes. These observations provide insight into the critical role played by $I L-1 \beta$ in tissue destruction and repair, and into the direct interaction between cytokines and growth factors associated with inflammatory arthropathy.

Nagasaki University School of Medicine, Sakamoto, Nagasaki, Japan

Department of

Orthopaedic Surgery

T Matsumoto

H Enomoto

K Iwasaki

Department of Cell Physiology, Atomic Disease Institute

T Tsukazaki

$S$ Yamashita

Correspondence to:

Dr Tomoko Matsumoto Department of Orthopedic Surgery, Nagasaki University School of Medicine, 1-7-1 Sakamoto, Nagasaki 852 , Japan.

Accepted for publication 12 October 1993
Interleukin-1 $\beta$ (IL-1 $\beta$ ) inhibits chondrostimulates the degradation of cartilage matrix. ${ }^{2-5}$ Chondrocytes are reported to produce IL-1 $\beta .^{6}$ Furthermore, the concencytes from producing proteoglycan and tration of IL-1 $\beta$ released from synovial cells, monocytes or macrophages in the synovial fluid of patients with rheumatoid arthritis is reported to be elevated. ${ }^{78}$ This cytokine is thought to regulate the local metabolism of chondrocytes in an autocrine/paracrine fashion. Its precise function, however, is still unknown. There is a report that IL- $1 \beta$ appears during the early phase of wound healing and is important for triggering repair. ${ }^{9}$ In articular cartilage, tissue repair is seen in the early phase of osteoarthritis. ${ }^{10}$ After injection of IL- $1 \beta$ into the rabbit knee joint, glycosaminoglycan synthesis was initially depressed, but at one week the rate of synthesis had almost doubled compared with the normal side. ${ }^{11}$ In addition, IL-1 receptor antagonist protein has recently been reported to be effective as a form of gene therapy in experimental arthritis. ${ }^{12}$

Insulin-like growth factor I (IGF-I) plays an important role in increasing matrix synthesis ${ }^{13} 14$ and the expression of IGF-I mRNA in articular chondrocytes is increased in osteoarthritis. ${ }^{15}$ This evidence indicates the possibility of tissue repair in articular chondrocytes due to the increase of growth factors, such as IGF-I, in response to cytokines such as IL- $1 \beta$. This study was therefore carried out to clarify the effects of IL-1 $\beta$ on cultured articular chondrocytes and to determine whether or not this regulates IGF-I, IGF-binding proteins (BP) production, and the relevant levels in these cells. The role played by IGF-I in the autocrine/paracrine axis in inflammatory arthropathy was also examined.

\section{Materials and methods}

MATERIALS

Recombinant human IL-1 $\beta$ (specific activity $1 \times 10^{7} \mathrm{U} / \mathrm{mg}$ ) was a gift from Otsuka Pharmaceutical (Tokushima, Japan); the IGFI assay kit developed by the Nichols Institute was supplied by Eiken Chemical (Tokyo, Japan). The prostaglandin E2 (PGE2) RIA kit and $\left.{ }^{125} \mathrm{I}\right]$-Iodotyrosyl IGF-I were purchased from Amersham International (Tokyo, Japan). Eagle's Minimum Essential Medium was obtained from Nissui Pharmaceutical (Tokyo, Japan) and fetal bovine serum from Gibco (Grand Island, NY). Collagenase type 2A was obtained from Sigma Chemical (St Louis, MO). The other materials used were commercial products of the highest grade available. 
CHONDROCYTE CULTURE

Chondrocytes were isolated from the articular cartilage of five week old male Sprague-Dawley rats, in accordance with methods detailed elsewhere. ${ }^{16}$ Each experiment involved 10 rats. In brief, cartilage removed from both the shoulders and the femurs was dissected into small pieces. The pieces were treated with trypsin for 30 minutes, followed by a two hour treatment with $0 \cdot 2 \%$ collagenase. The cells released after digestion were seeded at $1 \times 10^{5}$ cells $/ \mathrm{ml}$ in Eagle's MEM medium containing $10 \%$ fetal bovine serum plus glutamine and were grown to confluence in an atmosphere of $5 \% \quad \mathrm{CO}_{2} / 95 \%$ air at $37^{\circ} \mathrm{C}$. When primary cultures reached confluency, the monolayers were washed with PBS and enzymatically detached by a mixture of $0.1 \%$ trypsin and $0.02 \%$ EDTA, and subcultured for the definitive experiments. Cells were seeded into $100 \mathrm{~mm}$ diameter dishes for RNA preparation and IGFBP detection, into 24-well plates for other assays, at a density of $1 \times 10^{4}$ cells $/ \mathrm{cm}^{2}$ in Eagle's MEM with $10 \%$ FCS.

\section{MEASUREMENT OF IGF-1 PRODUCTION}

Medium IGF-I concentration was measured with a RIA, using the commercially available human IGF-I assay kit developed by the Nichols Institute with a rabbit polyclonal antihuman IGF-I antiserum. The sensitivity of IGF-I was $0.05 \mathrm{ng} / \mathrm{nl}$. This IGF-I kit measures free IGF-I, and there was no cross reactivity with IGF-II and insulin. The samples were neither extracted nor treated before the kit was used to determine the IGF-I levels.

MEASUREMENT OF PGE2 PRODUCTION

PGE2 concentration in the medium was determined with an RIA kit. Before analysing extracted samples using this assay system it is necessary to convert extracted prostaglandin $\mathrm{E}_{2}$ into its methyl oximate derivative using the methyl oximation reagent provided.

DETECTION OF IGF-BINDING PROTEINS

To analyse IGFBP, chondrocytes were cultured to confluence in tissue culture plates (100 mm diam) in Eagle's MEM containing $10 \% \mathrm{FCS}$, and then incubated for a further 24 hours in $5 \mathrm{ml}$ serum-free medium. Test substances (IL-1 $\beta$, Indomethacin) were added in the medium and incubations were continued for 24 hours. Conditioned medium $(5 \mathrm{ml})$ were collected and concentrated 20 -fold by lyophilisation, which was then reconstituted in Laemmli sample buffer in preparation for electrophoretic analysis. ${ }^{17}$ Prepared samples and standards were fractionated under nonreducing conditions on $12 \%$ SDS-polyacrylamide gels for four hours at $100 \mathrm{~V}$, then transferred electrophoretically to nitrocellulose membrane. After electroblotting, IGFBP were detected by a ligand blotting method described by Hossenlopp et al. ${ }^{18}$ Briefly, the membrane was soaked first for 30 minutes in saline $(0 \cdot 15$ $\mathrm{M} \mathrm{NaCl}-0.01 \mathrm{M}$ Tris $\mathrm{HCl}, \mathrm{Ph} 7.4$ ) containing
$3 \%$ Nonidet P-40, then for two hours in saline containing $1 \% \mathrm{BSA}$, and finally for 10 minutes in saline containing $0.1 \%$ Tween-20. It was then exposed to $400000 \mathrm{cpm} / \mathrm{ml}\left[{ }^{125} \mathrm{I}\right] \mathrm{IGF}-\mathrm{I}$ in saline and incubated overnight. The membrane was washed in saline and exposed to Kodak film for four days at $-70^{\circ} \mathrm{C}$.

\section{[125I]IGF-I BINDING STUDY}

Cells were plated at a density of $2 \times 10^{4}$ cells/ well in 24-multiwells in Eagle's MEM containing $10 \%$ FCS. When the cultures reached confluency, the medium was replaced with $1 \mathrm{ml}$ serum-free medium and maintained for 24 hours, and then incubated with or without IL-1 $\beta$ for a further 24 hours; $1.2 \times 10^{5}$ cells/well were used for these binding studies. After the medium was aspirated, monolayers were washed with phosphate buffered saline and then incubated with $\left[{ }^{125} \mathrm{I}\right]$-labelled IGF-I $(50000 \mathrm{cpm})$ plus various concentrations of unlabelled IGF-I. After incubations were carried out at $4^{\circ} \mathrm{C}$ for 12 hours, cell layers were rinsed twice with cold PBS and solubilised to determine radioactivity in a gamma counter.

\section{RNA EXTRACTION AND NORTHERN BLOT}

\section{ANALYSIS}

Chondrocyte RNA was extracted with acidguanidium thiocyanate and phenol chloroform. ${ }^{19}$ Thirty micrograms of total RNA was denatured and separated by electrophoresis on $1 \%$ agarose formaldehyde gel as described previously. ${ }^{20}$ After electrophoresis, the RNA was blotted on to a nitrocellulose membrane. It was then prehybridised and hybridised with a ${ }^{32} \mathrm{P}$-labelled cDNA probe. Hybridisation signals were detected by exposure to $x$ ray film at $-70^{\circ} \mathrm{C}$. Mouse IGF-I cDNA was provided by G I Bell. ${ }^{21}$ To confirm the specificity of articular chondrocytes, we used rat $\alpha 1$ (II) collagen cDNA and rat aggrecan cDNA, provided by Y Yamada. ${ }^{22-24}$

Values were expressed as the mean (SEM). Data were compared using Student's 2-tailed $t$-test, and $\mathrm{p}$ values less than 0.05 were considered significant.

\section{Results \\ Cell specificity in rat articular chondrocytes}

As we used second passaged rat chondrocytes, we tried to ascertain whether the specific characteristics of articular chondrocytes were maintained. Type II collagen and aggregan were selected as chondrocyte-specific markers. Type II collagen mRNA species $(5 \cdot 5 \mathrm{~Kb})$ and aggrecan mRNA expression $(9 \mathrm{~Kb})$ were detected (fig 1). These results confirmed that the chondrocytes used in these studies had the characteristics of articular chondrocytes in that they produced type II collagen and aggregan.

EFFECTS OF IL-1 $\beta$ ON IGF-I LEVELS IN THE CULTURE MEDIUM

Confluent cultured rat articular chondrocytes were incubated with IL-1 $\beta(1-200 \mathrm{U} / \mathrm{ml})$ in 

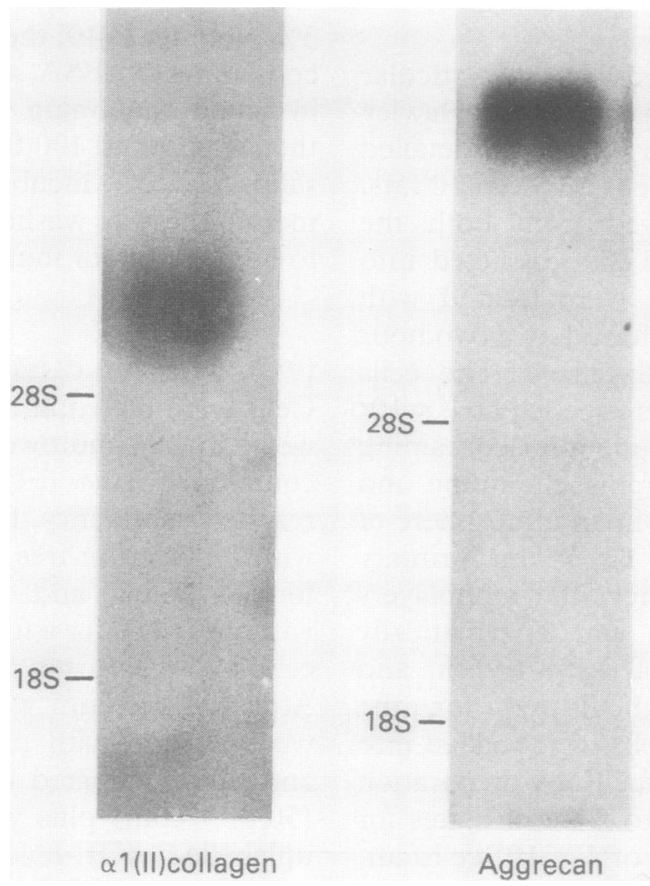

Figure 1 Expression of $\alpha 1$ (II) collagen and aggrecan $m R N A$. The second passaged cells were subjected to Northern gel analvisi, as described in Materials and methods. $\alpha$ I (II) collagen InRNA was detected in size $5.5 \mathrm{~kb}$, aggreqan mRNA acas detected in about $9 \mathrm{~kb}$.

serum-free medium for 24 hours, and the conditioned media were assayed for IGF-I. IL$1 \beta$ stimulated the release of IGF-I at $50 \mathrm{U} / \mathrm{ml}$ and higher concentrations. The maximal stimulation of IGF-I release was relatively constant after stimulation with IL- $1 \beta$ at 50 to $200 \mathrm{U} / \mathrm{ml}$ (fig 2). Further stimulation by IL-1 $\beta$ was not observed after 48-72 hours of treatment (data not shown).

The effects of indomethacin and cyclohexamide on IL-1 $\beta$-induced IGF-I release were also examined. The chondrocytes were stimulated with IL-1 $\beta(2-200 \mathrm{U} / \mathrm{ml})$ in serumfree medium for 24 hours and the conditioned media were assayed for PGE2. With increasing concentrations of $\mathrm{IL}-1 \beta$, the PGE2 levels were notably elevated. When indomethacin $(5 \mu \mathrm{g} / \mathrm{ml})$ was added, in the presence of IL- $\beta$,

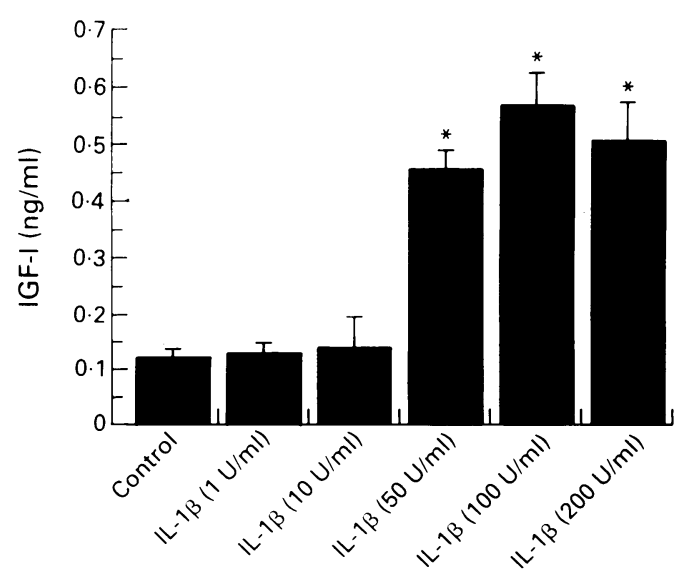

Figure 2 IGF-I levels in culture medium after 24 hour

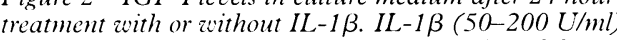
significantly increased the IGF-I concentration of the medium. [ $n=4$, mean (SE), $\left.{ }^{*} p<0.001\right]$.

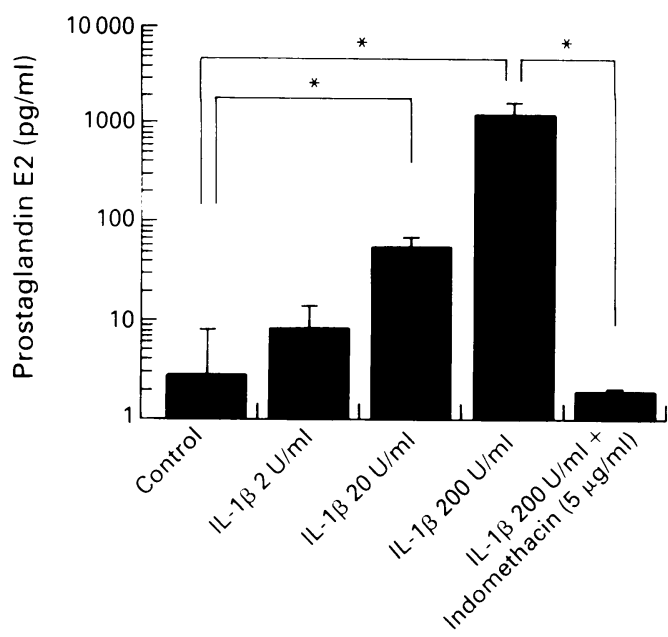

Figure 3 Prostaslandin Ez lezels in culture medium after

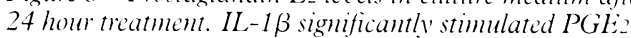
levels in the chondrocytes medium, howerer, indomethacin $(5 \mu \mathrm{g} / \mathrm{ml})$ completely blocked the svinthesis of P( $\mathrm{Fl}, 2$ [n $=4$, mean (SE), $\left.{ }^{\star} p<0 \cdot 001\right]$.

the synthesis of PGE2 was completely blocked (fig 3).

However, indomethacin did not inhibit the release of IGF-I induced by IL-1 13 , although cyclohexamide, a protein synthesis inhibitor, significantly reduced the IGF-I secretion induced by IL,-1 $\beta$ (fig 4 ).

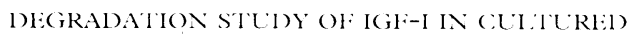
MEDIA

Using two different methods, we examined whether IGF-I in the medium was degraded by IL $-1 \beta$.

(1) $\left[{ }^{125} \mathrm{I}\right] \mathrm{IGF}-\mathrm{I}(100000 \mathrm{cpm} /$ well $)$ was added to the serum-free medium of confluent chondrocytes with or without added IL $-1 \beta$ and the degradation of this radiolabelled ligand was determined by measuring the radioactivity. Incubation medium, collected at various times, was mixed with $10 \%$ trichloroacetic acid. After 30 minutes of incubation at $4^{\circ} \mathrm{C}$, the radioactivity of the precipitate was determined in a

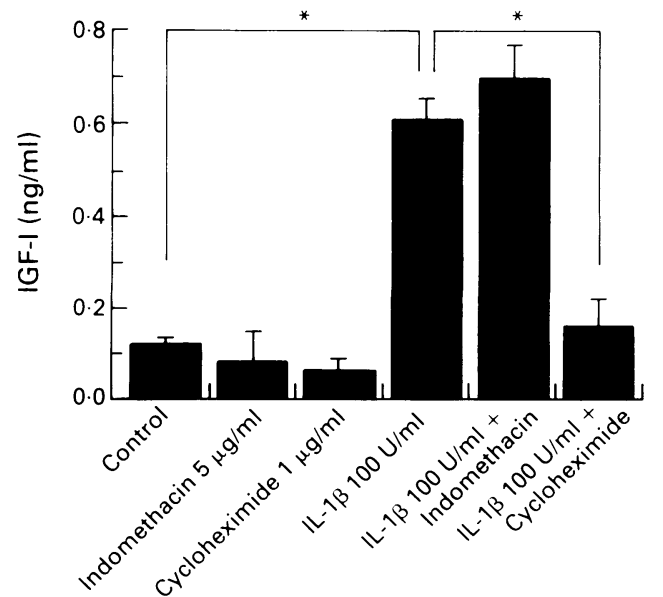

Figure 4 Effects of indomethacin and cyclohexamide on IL-1 $\beta$-induced IGF-I secretion. Indomethacin $(5 \mu \mathrm{g} / \mathrm{ml})$ did not inhibit this secretion, while cyclohexamide (1 $\mu \mathrm{g} / \mathrm{ml}$ ) significantly inhibited it. $/ n=4$, mean (SE), $\left.{ }^{*} p<0 \cdot 001\right]$. 


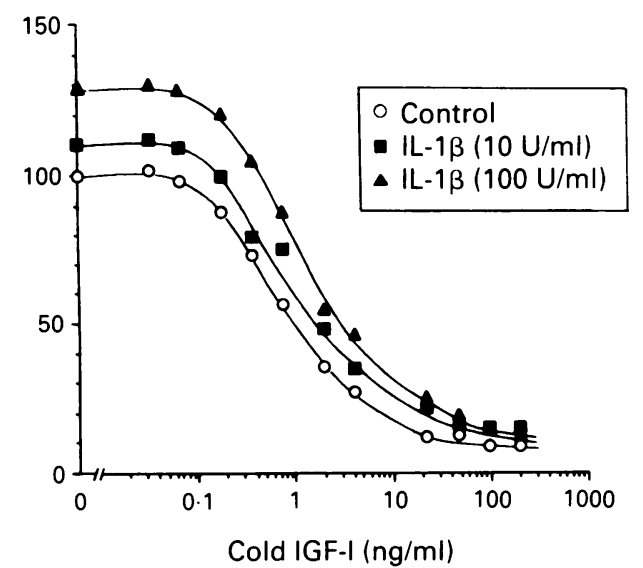

Figure 5 Displacement of $\Gamma^{125}$ IJIGF-I from rat articular chondrocyte monolayers by increasing concentrations of unlabelled IGF-I $(0.01-200 \mathrm{ng} / \mathrm{ml}) .(n=3$.

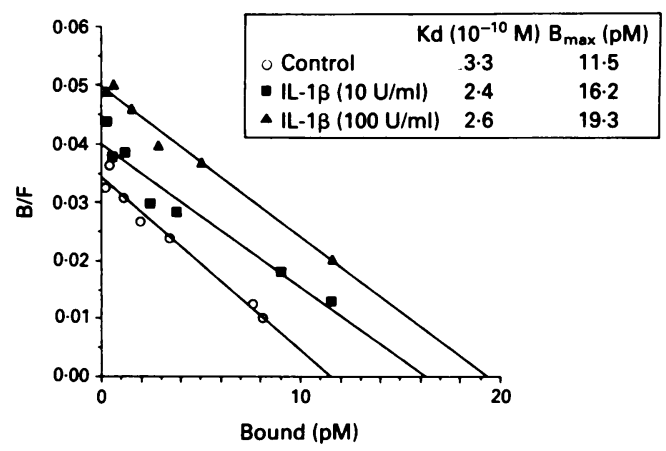

Figure 6 Scatchard analysis of IGF-I specific binding in rat articular chondrocyte with or without added $I L-1 \beta$. The $K d$ values, which means binding affinity, reflected by the slopes are similar, but the Bmax, which means overall binding capacity, derived from abscissa intercept is greater for articular chondrocytes treated with IL-1 $\beta$ than that for cells not so treated.

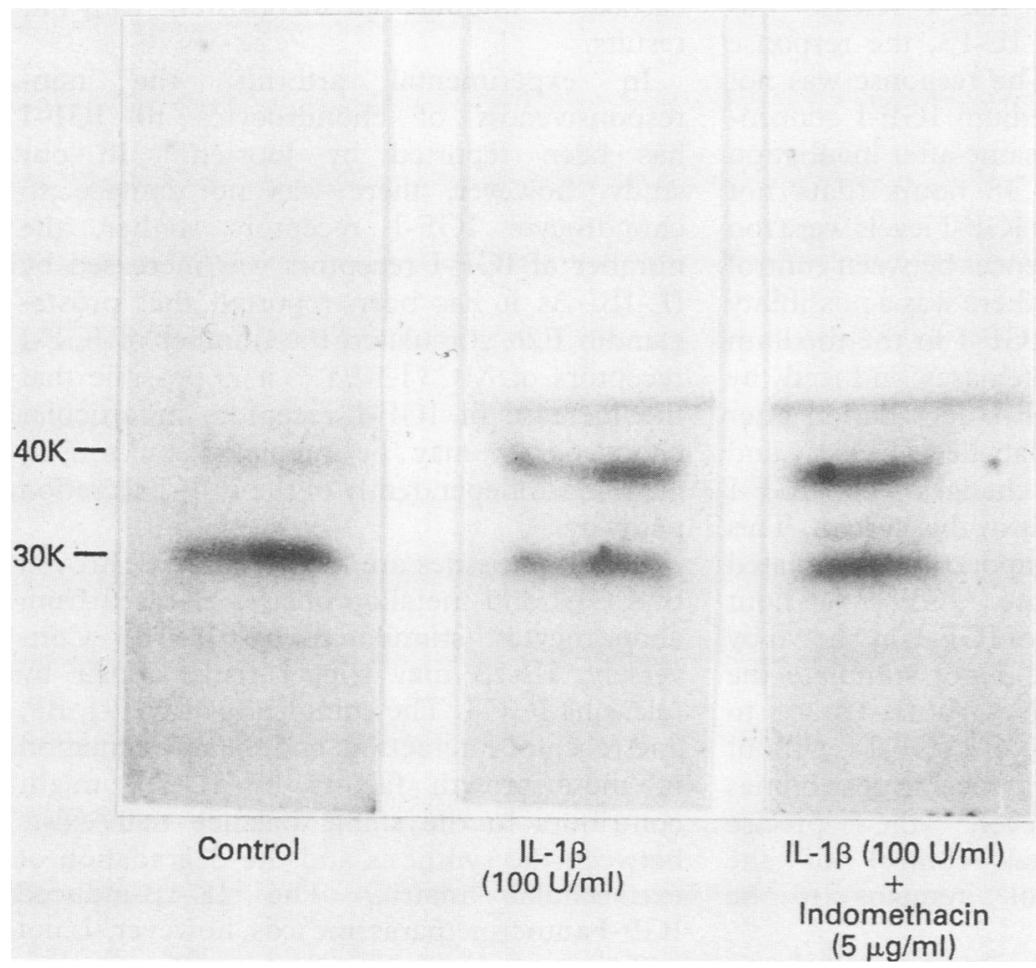

Figure 7 Western blot analysis of IGF binding proteins in culture medium. Samples were fractionated on $12 \%$ SDS-polyacrylamide gels and then transferred on to nitrocellulose membrane. After electroblotting, the membrane was soaked for 30 minutes in saline membrane. After electroblotting, the membrane was soaked for 30 minutes in saline
$(0 \cdot 15 \mathrm{M} \mathrm{NaCl}-0 \cdot 01 \mathrm{M}$ Tris $\mathrm{HCl}$, $\mathrm{H} 7.4$ ) containing $3 \%$ Nonidet $P-40$, then for two hours in saline containing $1 \% B S A$, and finally for 10 minutes in saline containing $0 \cdot 1 \%$ Tween-20. It was then exposed to $400000 \mathrm{cpm} / \mathrm{ml}$ [125I]IGF-I in saline and incubated overnight. The membrane was then washed in saline and exposed to Kodak film for four days at $-70^{\circ} \mathrm{C}$.

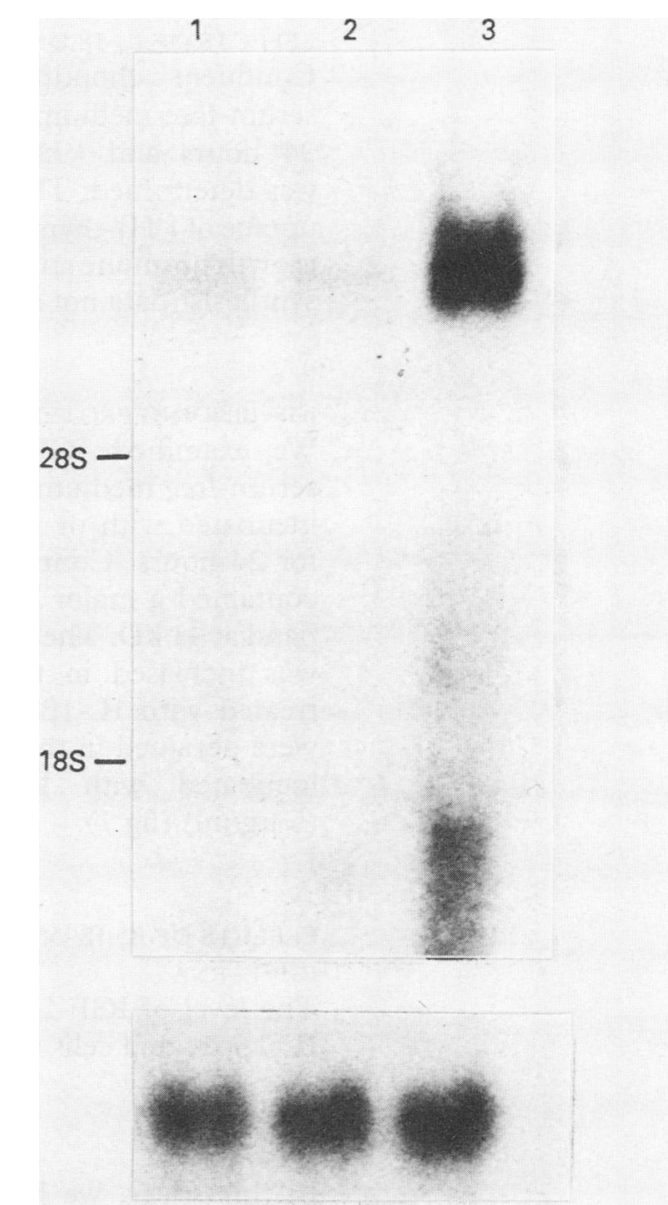

Figure 8 Northern gel analysis of IGF-I $m R N A$ expression in cultured articular chondrocytes. Lane 1; control, lane 2; IL-1 $\beta$ treatment. Lane 3 shows IGF-I $m R N A$ extracted from MC3T3-E1. Cultured chondrocytes $\left(1 \times 10^{6}\right)$ were subjected to total $R N A$ extraction. Each lane contained $30 \mu \mathrm{g}$ of total $R N A$. After hybridisation with $\left.\Gamma^{32} P\right]-m I G F-I c D N A$, the blot paper was autoradiographed for 48 hours, as described in the Method section. The same paper was washed and then IGF-I $m R N A$ was detected in size $9 \mathrm{~kb}$.

gamma counter (Aloka). The results were expressed as percentages of the radioactivity in the control medium without IL-1 $\beta$. There was no significant difference in the time courses (data not shown).

(2) Unlabelled IGF-I ( $50 \mathrm{ng} / \mathrm{ml})$ was added to the serum-free medium of confluent chondrocytes with or without IL-1 $\beta$. IGF-I content in the medium was determined by RIA at various times. No degradation of the IGF-I medium occurred in the presence of IL-1 $\beta$ during 40 hour incubation (data not shown).

\section{[125] IGF-I BINDING ON CHONDROCYTES}

Figure 5 shows the binding of $\left[{ }^{125} \mathrm{I}\right] \mathrm{IGF}-\mathrm{I}$ to chondrocytes incubated with various concentrations of unlabelled IGF-I. Half maximal binding was obtained at a concentration of $1 \mathrm{ng} / \mathrm{ml}$ and that of $1.5 \mathrm{ng} / \mathrm{ml}-$ $2 \mathrm{ng} / \mathrm{ml}$ in the IL-1 $\beta$ treated cells. Scatchard analysis showed that the dissociation constant $(\mathrm{Kd})$ of IGF-I binding was similar for control and IL-1 $\beta$-treated cells. In contrast, the number of IGF-I receptors per cell was significantly increased, in a dose-dependent manner, after the addition of IL-1 $\beta$ (fig 6 ). 
EFFECTS OF IL-1 $\beta$ ON DNA SYNTHESIS

Confluent chondrocytes were cultured in serum-free medium with or without IL- $1 \beta$ for 24 hours and $\left[{ }^{3} \mathrm{H}\right]$-thymidine incorporation was determined. There was no increase in the uptake of $\left[{ }^{3} \mathrm{H}\right]$-thymidine. However, IGF-I and growth hormone stimulated chondrocyte DNA synthesis (data not shown).

IGF-BINDING PROTEINS IN THE MEDIUM

We examined IGF-binding proteins in the serum-free medium of confluent chondrocytes incubated with or without IL-1 $\beta(100 \mathrm{U} / \mathrm{ml})$ for 24 hours. Control medium without IL-1 $\beta$ contained a major band at $30 \mathrm{kD}$ and a faint band at $41 \mathrm{kD}$. The intensity of the $41 \mathrm{kD}$ band was increased in the medium when it was treated with IL-1 $\beta$. Almost the same results were obtained in the medium of chondrocytes incubated with IL-1 $\beta$ and indomethacin (5 $\mu \mathrm{g} / \mathrm{ml}$ ) (fig 7).

EFFECTS OF IL- $1 \beta$ ON THE EXPRESSION OF IGF-I mRNA

The level of IGF-I mRNA was not altered in IL-1 $\beta$-treated cells (fig 8).

\section{Discussion}

In this study, we have demonstrated for the first time that IL-1 $\beta$ stimulates articular chondrocytes to release IGF-I and IGFBP into culture medium. The specificity and properties of articular chondrocytes after treatment were confirmed by the presence of type II collagen and aggrecan mRNAs. IGF-I release was observed at $50 \mathrm{U} / \mathrm{ml}$ of IL- $1 \beta$, the response being dose-dependent. The response was not time-dependent, and medium IGF-I concentrations were almost the same after incubation with IL-1 $\beta$ for 24 and 48 hours (data not shown). The intracellular IGF-I levels were too low to compare the differences between control and IL- $1 \beta$ treatment. As there was a possibility that the degradation of IGF-I in the medium was modulated by proteinases induced by IL- $1 \beta$, we examined IGF-I degradation after adding labelled or unlabelled IGF-I, and confirmed that the changes of IGF-I degradation did not occur in this system. This shows that IL-1 $\beta$ temporarily stimulated chondrocytes to release IGF-I without stimulating the synthesis of IGF-I, as shown by the finding that IL-1 $\beta$ did not stimulate the expression of IGF-I mRNA. As IL-1 $\beta$ acts to increase the secretion of IGF-I without affecting its mRNA level, several possibilities are proposed. However, the precise mechanism, translational control of the IGF-I secretary control, remains to be clarified.

IL-1 is reported to stimulate mouse calvaria to produce IGF-I by a prostaglandindependent mechanism, ${ }^{25}$ and PGE2 has been reported to stimulate IGF-I production in rat osteoblast enriched cultures. ${ }^{26}$ In our study, however, indomethacin $(5 \mu \mathrm{g} / \mathrm{ml})$ did not block the release of IGF-I from chondro- cytes stimulated by IL- $1 \beta$, which is considered to be a PGE2-independent mechanism. In contrast, the findings that cyclohexamide inhibited IGF-I production demonstrated that new protein synthesis was required for IL- $1 \beta$ to exert its action on the release of IGF-I.

IGFBP play an important role in regulating IGF availability. ${ }^{27}$ IGFBP in human serum consist of five molecular forms, $41.5,38.5,34$, 30 and $24 \mathrm{kD} ; 41.5$ and $38.5 \mathrm{kD} \mathrm{BP}$ are regulated by growth hormone, corresponding to IGFBP-3. ${ }^{28}$ It is reported that IGFBP-3 was not detected in rabbit chondrocytes medium, but that the $30 \mathrm{kD}$ form was predominant. ${ }^{29}$ In this study, we showed that rat chondrocytes produced two major bands of IGFBP, that is, 30 and $41 \mathrm{kD}$. In the control medium the 30 $\mathrm{kD}$ band was distinct, while the $41 \mathrm{kD}$ band increased after the addition of IL-1 $\beta$. This 41 $\mathrm{kD}$ band corresponds to IGFBP-3 in human serum. However, the exact role of the $41 \mathrm{kD}$ $\mathrm{BP}$ is still unknown.

The concentration of IGF-I induced by IL-1 $\beta$ in the medium was too low (less than $0.5 \mathrm{ng} / \mathrm{ml}$ ) to affect the proliferation of chondrocytes by an autocrine mechanism. That these levels of IGF-I do not overcome the inhibitory effect of IL-1 $\beta$ on DNA synthesis is shown by findings that the incorporation of ${ }^{3} \mathrm{H}$-thymidine or ${ }^{35} \mathrm{~S}$-sulphate in rabbit chondrocytes was stimulated by IGF-I at concentrations of over $10 \mathrm{ng} / \mathrm{ml}^{30}$ Furthermore, a $100 \mathrm{ng} / \mathrm{ml}$ concentration of IGF-I was necessary for the inhibition of IL-I induced matrix degradation of proteoglycans in an explant culture of pig articular cartilage, ${ }^{31}$ findings not inconsistent with our results.

In experimental arthritis, the nonresponsiveness of chondrocytes to IGF-I has been reported by Joosten. ${ }^{32}$ In our study, however, there was no damage to chondrocyte IGF-I receptors, rather, the number of IGF-I receptors was increased by IL-1 $\beta$. As it has been reported that prostaglandin $F 2 \alpha$ stimulated the number of IGF-I receptors of $M C 3 T 3-E 1,{ }^{33}$ it is possible that the increase of IGF-I receptors in articular chondrocytes may be mediated by prostaglandins, independently of the IGF-I secretion pathway.

Cartilage tissues are known to be destroyed by PGE2 and metalloproteases released from chondrocytes stimulated by IL-1 $\beta$. Conversely, IL-1 $\beta$ may trigger tissue repair by releasing IGF-I. The complexity of IGF-I, BP, and receptor interaction, and the up-regulation of these growth factors by IL-1 $\beta$, might contribute to the stable balance that exists between the synthesis and the degradation of extracellular matrix. The IL-1 $\beta$-induced IGF-I autocrine/paracrine axis, however, is not sufficient to repair tissue destruction.

In conclusion, various cytokines and growth factors may be important in promoting the repair of articular cartilage degradation. IL-1 $\beta$ may affect the post-receptor pathways of IGFI signal transduction to inhibit tissue repair in the articular cartilage. 
1 Dingle J T. Cartilage maintenance in osteoarthritis: Interaction of cytokines, NSAID and prostaglandins in articular cartilage damage and repair. $f$ Rheumatol (suppl) 1991; 18: 30-7.

2 Verschure P J, Van Noorden C J F. The effects of interleukin-1 on articular cartilage destruction as interleukin-1 on articular cartilage destruction as observed in arthritic diseases, and its
Clin Exp Rheumatol 1990; 8: 303-13.

3 Chandrasekhar S, Harvey A, Hrubey P S. Intra-articular administration of interleukin-1 causes prolonged suppression of cartilage proteoglycan synthesis in rats. Matrix 1992; 11: 1-10.

4 Verbruggen G, Veys E M, Malfait A M, De Clercq L, Van Den Bosch F, De Vlam $K$. Influence of human recombinant interleukin-1 $\beta$ on human articular cartilage. Mitotic activity and proteoglycan metabolism. Clin Exp Rheumatol 1991; 9: 481-8.

5 Arner E C, Pratta M A. Independent effects of interleukin1 on proteoglycan breakdown, proteoglycan synthesis and prostaglandin E2 release from cartilage in organ culture. prostaglandin E2 release from car
Arthritis Rheum 1989; 32: 289-97.

6 Towle C A, Trice M E, Ollivierre F, Awbrey B J, Treadwell $B$ V. Regulation of cartilage remodeling by IL-1: Evidence for autocrine synthesis of IL-1 by chondrocytes. F Rheumatol 1987; 14: 11-3.

7 Duff G W. Peptide regulatory factors in non-malignant disease. Lancet 1989; i: 1432-4.

8 Arend W P, Dayer J-W. Cytokines and cytokine inhibitors or antagonists in rheumatoid arthritis. Arthritis Rheum 1990; 33: 305-15.

9 Fahey III T J, Sherry B, Tracey K J, et al. Cytokine production in a model of wound healing: The appearance of MIP-1, MIP.

10 Mankin $\mathrm{H}$ J, Lippiello L. Biochemical and metabolic abnormalities in articular cartilage from osteoarthritic human hips. F Bone foint Surg 1970; 52-A: 424-34

11 Page Thomas D P, King B, Stephens T, Dingle J T. In vivo studies of cartilage regeneration after damage induced by cataboline/interleukin-1. Ann Rheum Dis 1991; 50: 75-80.

12 Bandara G, Robbins P D, Georgescu H I, Mueller G M Glorioso J C, Evans C H. Gene transfer to synoviocytes; Prospects for gene treatment of arthritis. DNA and Cell Biology 1992; 11: 227-31.

13 Demarquay D, Dumontier M F, Tsagris L, Bourguignon J, Nataf V, Corvol M T. In vitro Insulin-like growth factor I interaction with cartilage cells derived from postnatal animals. Horm Res 1990; 33: 111-5.

14 Tyler J A. Insulin-like growth factor I can decrease degradation and promote synthesis of proteoglycan in cartilage exposed to cytokines. Biochem 7 1989; 260: 543-8.

15 Middleton J F S, Tyler J A. Upregulation of insulin-like growth factor I gene expression in the lesion of osteoarthritic human articular cartilage. Ann Rheum Dis 1992; 51: 440-7.

16 Shimomura Y, Yoneda T, Suzuki F. Osteogenesis by chondrocytes from growth cartilage of rat rib. Calcif Tissue Res 1975; 19: 179-87.

17 Laemmli U K. Cleavage of structural proteins during the assembly of the head bacteriophage T4. Nature 1970; 227: $680-5$.

18 Hossenlopp P, Seurin D, Segovia-Quinson B, Hardouin S, Binoux $M$. Analysis of serum insulin-like growth factor binding proteins using Western blotting: use of method for titration of the binding proteins and competitive binding studies. Anal Biochem 1986; 154: 138-43.

19 Chomcznski P, Sacchi N. Single step method of RNA isolation by acid guanidium thiocyanate-phenolchloroform extraction. Anal Biochem 1987; 162: 156-9.

20 Yamashita S, Melmed S. Effects of insulin on rat anterior pituitary cells: inhibition of growth hormone secretion and mRNA levels. Fournal 1986; 35: 440-7.

21 Bell G I, Stempien M M, Fong N M, Rall L B. Sequences of liver $\mathrm{CDNAs}$ encoding two different mouse insulin-like growth factor I precursors. Nucleic Acid Res 1986; 14: 7873-82.

22 Kohno K, Martin G R, Yamada Y. Isolation and characterization of a cDNA clone for the amino-terminal portion of pro- $\alpha 1$ (II) chain of cartilage collagen. $f$ Biol Chem 1984; 259: 13668-73.

23 Doege K, Fernandez P, Hassell J R, Sasaki M, Yamada Y. Partial cDNA sequence encoding a globular domain at the $\mathrm{c}$ terminus of the rat cartilage proteoglycan. $\mathcal{F}$ Biol Chem 1986; 261: 8108-11.

24 Doege K, Sasaki M, Horigan E, Hassell J R, Yamada Y. Complete primary structure of the rat cartilage proteoglycan core protein deduced from cDNA clones. $\mathcal{F}$ Biol Chem 1987; 262: 17757-67.

25 Linkhart T A, MacCharles D C. Interleukin-1 stimulates release of insulin-like growth factor-I from neonatal mouse calvaria by a prostaglandin synthesis-dependent mechanism. Endocrinology 1992; 131: 2297-305.

26 McCarthy T L, Centrlla M, Raisz L G, Canalis E. Prostaglandin E2 stimulates insulin-like growth factor I synthesis in osteoblast-enriched cultures from rat bone. Endocrinology 1991; 128: 2895-900.

27 Baxter R C. Insulin-like growth factor (IGF) binding proteins: the role of serum IGFBPs in regulating IGF availability. Acta Paediatr Scand (suppl) 1991; 372: 107-14.

28 Hardouin S, Gourmelen M, Noguiez P, et al. Molecular forms of serum insulin-like growth factor (IGF) - binding proteins in man: relationships with growth hormone and IGFs and physiological significance. $\mathcal{f}$ Clin Endocrinol Metab 1989; 69: 1291-301.

29 Froger-Gaillaard B, Hossenlopp P, Adolphe Monique, Binoux M. Production of insulin-like growth factors and their binding proteins by rabbit articular chondrocytes: relationships with cell multiplication. Endocrinology 1989; 124: 2365-72.

30 Trippel S B, Corvol M T, Dumontier M F, Rappaport R, Hung $\mathrm{H} \mathrm{H}$, Mankin $\mathrm{H} \mathrm{J}$. Effect of somatomedin$\mathrm{C} /$ insulin-like growth factor I and growth hormone on cultured growth plate and articular chondrocytes. Pediatr Res 1989; 25: 76-82.

31 Fosang A J, Tyler J A, Hardingham T E Effect of interleukin-1 and insulin-like growth factor-1 on the release of proteoglycan components and hyaluronan from release of proteoglycan components and hyaluronan from pig articul $17-24$.

32 Joosten L A B, Helsen M M A, Van den Berg W B. Transient chondrocyte nonresponsiveness to insulin-like growth factor-1 upon $\mathrm{H}_{2} \mathrm{O}_{2}$ exposure is not related to IGF receptor damage. $\mathcal{F}$ Rheumatol $1991 ; 18$ : 585-90.

33 Hakeda Y, Harada S, Matsumoto T, et al. Prostaglandin F2a stimulates proliferation of clonal osteoblastic MC3T3-E1 cells by upregulation of insulin-like growth factor I receptors. F Biol Chem 1991; 266: 21044-50. 